University of Nebraska - Lincoln

DigitalCommons@University of Nebraska - Lincoln

Nebraska Beef Cattle Reports

Animal Science Department

2020

\title{
Evaluation of the Water Footprint of Beef Cattle Production in Nebraska
}

Tyler J. Spore

University of Nebraska - Lincoln

Mesfin Mekonnen

Daugherty Water for Food Global Institute, mmekonnen2@unl.edu

Christopher M.U. Neale

University of Nebraska - Lincoln \& Daugherty Water for Food Global Institute, cneale@nebraska.edu

Andrea K. Watson

University of Nebraska at Lincoln, awatson3@unl.edu

James C. MacDonald

West Texas A\&M University \& University of Nebraska - Lincoln, jmacdonald2@unl.edu

See next page for additional authors

Follow this and additional works at: https://digitalcommons.unl.edu/animalscinbcr

Part of the Large or Food Animal and Equine Medicine Commons, Meat Science Commons, and the Veterinary Preventive Medicine, Epidemiology, and Public Health Commons

Spore, Tyler J.; Mekonnen, Mesfin; Neale, Christopher M.U.; Watson, Andrea K.; MacDonald, James C.; and Erickson, Galen E., "Evaluation of the Water Footprint of Beef Cattle Production in Nebraska" (2020).

Nebraska Beef Cattle Reports. 1071.

https://digitalcommons.unl.edu/animalscinbcr/1071

This Article is brought to you for free and open access by the Animal Science Department at DigitalCommons@University of Nebraska - Lincoln. It has been accepted for inclusion in Nebraska Beef Cattle Reports by an authorized administrator of DigitalCommons@University of Nebraska - Lincoln. 


\section{Authors}

Tyler J. Spore, Mesfin Mekonnen, Christopher M.U. Neale, Andrea K. Watson, James C. MacDonald, and Galen E. Erickson 


\section{Evaluation of the Water Footprint of Beef Cattle Production in Nebraska}

\author{
Tyler J. Spore \\ Mesfin M. Mekonnen \\ Christopher M. U. Neale \\ Andrea K. Watson \\ James C. MacDonald \\ Galen E. Erickson
}

\section{Summary with Implications}

Data were compiled on feed usage to model the amount of water needed to produce beef in typical Nebraska production systems. Production systems where cows were wintered on corn residue utilized 18\% less water than systems utilizing native range as a wintering source, because of water allocations. Therefore, the water footprint (gallons of water required to produce one pound of boneless meat) was decreased by $18 \%$. In addition, increasing the dietary inclusion of distillers grains from $0 \%$ to $40 \%$ decreased the water footprint in the finishing phase by $29 \%$, again based on water allocation. Utilizing corn residue and distillers grains in Nebraska beef cattle systems decreases the overall water footprint of production. Additionally, the water footprint of the systems analyzed was $80 \%$ green water as rain, minimizing the environmental impact of beef production on freshwater use and ecological water balance.

\section{Introduction}

Agriculture, especially beef cattle production, is accused of being one of the largest consumers of freshwater in the world. While modeling experiments have been conducted to estimate the amount of water needed to produce beef, the methods used to derive these values are commonly vague and results vary dramatically between studies. The variability in current estimates stems from three key sources. The greatest challenge currently is the water requirement of beef cattle production is

(C) The Board Regents of the University of Nebraska. All rights reserved. often not modeled as a system with varying inputs and outcomes, but rather reported as a single value. While this approach may be sufficient for vertically integrated livestock production systems, the technique does not accurately estimate water used by the beef industry as production is complex with numerous scenarios taking place between a calf's birth and slaughter. In addition, there is no consensus on the correct way to assign a water footprint to the feed resources used in cattle production with each model using a different technique. Lastly, the product produced is not always clearly defined. As a result, the water footprint varies significantly depending on whether it is expressed as water required per pound of carcass, pound of boneless beef, or pound of protein. Thus, the objective of this study was to properly model the water requirement of a specific beef production system commonly used in Nebraska from birth to slaughter, and to evaluate the impact of distillers grains in finishing diets on the water footprint.

\section{Procedure}

Data from 2010 Nebraska Beef Cattle Report, pp. 5-7 were analyzed to determine the effects of wintering strategy on the total amount of water used by the system. The study was conducted over 4 years utilizing 217 cows / yr. The objective of the referenced study was to determine the effects of calving date and wintering system on cow and calf performance. Dry matter intake (DMI), average daily gain (ADG), days on feed (DOF), and information on the specific finishing diets utilized were used to model the water footprint of this production system. Additionally, the Cattle CODE program (2008 Nebraska Beef Cattle Report, pp. 47-49) was used to model the effects of increasing distillers grains from $0 \%$ to $40 \%$ of the diet on performance of finishing cattle. Modeled intake and performance data were then used to evaluate the effects of distillers grains on the water footprint of finishing beef cattle.
The water footprint of the beef cattle system described in 2010 Nebraska Beef Cattle Report, pp. 5-7 was divided and calculated as two segments; the water footprint associated with the cow for one entire year, and the water associated with growing and finishing the calf. For the cow, the water footprint was calculated by adding the estimated amount of water directly consumed by the animal to the amount of water required to produce the forage that was grazed. Eight gallons was chosen to represent an average for daily water intake although diet, weather, and stage of lactation all influence water intake. A water footprint was also calculated for any supplements utilized while grazing. The water footprint for grazed forages was estimated using AUMs and rainfall data collected at GSL; the total amount of water as rain was divided by the amount of forage DM produced as estimated using the AUM. For grazing, a harvest efficiency of 50\% was assumed, meaning $50 \%$ of the grass produced was grazed while the other $50 \%$ was left. Rainfall associated with the $50 \%$ grazed or utilized by cattle was included as part of the water footprint for cattle production. Hay has a lower water footprint than native range due to assumptions of greater productivity on hayed acres (meadows) compared to native range. A similar technique was used for other feed sources (total water $/$ production $=$ water footprint $)$ except for distillers grains and corn residue. For both of these feeds, a strategy known as the value fraction method was applied. This method calculates the total revenue associated with a primary product and generates proportions based on the percentage of total revenue each co-product represents. For distillers grains, the value of this coproduct represents $19 \%$ of the total revenue generated during ethanol distillation thus the overall water footprint to produce corn grain is multiplied by 0.19 to arrive at the water footprint for distillers grains. Similarly, corn residue represents only $5 \%$ of the total revenue generated by a corn crop. 
Thus, the total amount of water required to produce the corn crop is multiplied by 0.05 , then that value is divided by the amount of corn residue produced per unit of corn that was used in the initial revenue calculation.

The total water footprint for the system described is further divided into what is known as a green and blue water footprint. Green water is the water associated with rainfall, and blue water represents the water removed from surface or ground water resources. For this system, the water required to produce grasses in the Sandhills is green water (rain), and any irrigation associated with producing row crops is defined as blue water. Lastly, the total amount of water required for the cow and finishing the calf is summed together and this value represents the total amount of water consumed by the system producing 1 beef carcass. This value is then divided by the amount of boneless meat produced. Water productivity was calculated as the inverse of the water footprint.

\section{Results}

The water footprint of ingredients used to model water utilization for the complete beef cattle system and the finishing scenario developed using Cattle Code are presented in Table 1. The effects of utilizing corn residue as a winter grazing source, calving date, and calf system on the water footprint of beef cattle production can be found in Tables 2-4, respectively. Production systems utilizing native range as a winter grazing source required on average 610,150 gallons of water (Table 2) to produce one finished beef calf across the three calving dates and yearling or calf-fed systems compared to systems utilizing corn residue which required 500,678 gallons to produce one finished beef calf. This represents an 18\% decrease in the amount of water required to produce beef when corn residue is substituted for native range as a winter grazing source. This assumes that corn residue was available for grazing in close proximity to the summer range and $95 \%$ of the water used to grow the corn was allocated to the corn grain. For both systems, over $80 \%$ of the water footprint was green, or rainwater. Total blue water use averaged $118 \mathrm{gal} / \mathrm{lb}$ of hot carcass weight (HCW) produced.

Month of calving and calving system (Table 3) have small impact on the system's overall water footprint because of the offsetting

Table 1. Water footprint of ingredients included in models ${ }^{1}$

\begin{tabular}{|c|c|c|c|}
\hline \multirow[b]{2}{*}{ Item } & \multicolumn{3}{|c|}{ Water footprint, gal / lb DM } \\
\hline & Green $^{2}$ & Blue $^{3}$ & Total \\
\hline \multicolumn{4}{|l|}{ Ingredient } \\
\hline \multicolumn{4}{|l|}{ Grazed forages } \\
\hline Corn Residue & 2 & 1 & 3 \\
\hline Sandhills Native Range & 36 & 0 & 36 \\
\hline \multicolumn{4}{|l|}{ Harvested Forages } \\
\hline Hay & 20 & 0 & 20 \\
\hline Alfalfa & 70 & 39 & 109 \\
\hline \multicolumn{4}{|l|}{ Harvested grains } \\
\hline Dry rolled corn & 51 & 25 & 76 \\
\hline Corn processing byproducts ${ }^{4}$ & 28 & 14 & 41 \\
\hline \multicolumn{4}{|c|}{ Ingredients from 2010 Nebraska Beef Cattle Report, pp. 5-7 and scenario generated using Cattle CODE } \\
\hline \multicolumn{4}{|l|}{${ }^{2}$ Rain water utilized } \\
\hline \multicolumn{4}{|l|}{${ }^{3}$ Surface and ground water utilized } \\
\hline Distillers grains and corn gluten feed & & & \\
\hline
\end{tabular}

Table 2. Effects of wintering system on beef cattle system water utilization ${ }^{1}$

\begin{tabular}{|c|c|c|}
\hline \multirow[b]{2}{*}{ Item } & \multicolumn{2}{|c|}{ Wintering system } \\
\hline & Native Range & Corn Residue \\
\hline \multicolumn{3}{|l|}{ Total Water use, gal } \\
\hline Green $^{2}$ & 507,050 & 399,185 \\
\hline Blue $^{3}$ & 103,100 & 101,492 \\
\hline Total & 610,150 & 500,678 \\
\hline \%Green & 83 & 80 \\
\hline$\%$ Blue & 17 & 20 \\
\hline \multicolumn{3}{|l|}{ Hot Carcass } \\
\hline Yield, lb & 876 & 866 \\
\hline Blue WF, gal / lb & 118 & 117 \\
\hline Total WF, gal / lb $\mathrm{lb}^{4}$ & 697 & 578 \\
\hline Total WP, lb / gal $^{5}$ & 0.00144 & 0.00173 \\
\hline \multicolumn{3}{|l|}{ Boneless meat ${ }^{6}$} \\
\hline Yield, lb & 613 & 606 \\
\hline Blue WF, gal / lb & 168 & 167 \\
\hline Total WF, gal / lb & 995 & 826 \\
\hline Total WP, lb / gal & 0.00100 & 0.00121 \\
\hline \multicolumn{3}{|c|}{$\begin{array}{l}{ }^{1} \text { Modeled using data from } 2010 \text { Nebraska Beef Cattle Report, pp. 5-7; water utilization was calculated over } 365 \text { days for cows } \\
\text { their respective systems and calf-system data averaged }\end{array}$} \\
\hline \multicolumn{3}{|l|}{${ }^{2}$ Rain water utilized } \\
\hline \multicolumn{3}{|c|}{${ }^{3}$ Surface and ground water utilized } \\
\hline \multicolumn{3}{|c|}{${ }^{4} \mathrm{WF}=$ water footprint $($ water unit $/$ carcass or boneless meat) } \\
\hline${ }^{5} \mathrm{WP}=$ water productivity $(\mathrm{ca}$ & ter unit) & \\
\hline
\end{tabular}

differences in feed inputs and HCW. However, August calving systems tended to have the smallest water footprint as all the cows in that system were wintered on corn stalks.

For the comparison between calf-fed and yearling finished cattle (Table 4), the yearling cattle were older at slaughter requiring more feed overall; however, the yearling system utilized slightly less water as the water footprint of the grasses grazed was lower than the total mixed ration utilized in the calf-fed scenario. 
Table 3. Effects of month of calving on beef cattle system water utilization ${ }^{1}$

\begin{tabular}{|c|c|c|c|}
\hline \multirow[b]{2}{*}{ Item } & \multicolumn{3}{|c|}{ Month of calving } \\
\hline & March & June & August \\
\hline \multicolumn{4}{|l|}{ Water use, gal } \\
\hline Green $^{2}$ & 425,870 & 466,662 & 399,346 \\
\hline Blue $^{3}$ & 95,010 & 106,602 & 100,167 \\
\hline Total & 520,879 & 573,264 & 499,513 \\
\hline$\%$ Green & 82 & 81 & 80 \\
\hline$\%$ Blue & 18 & 19 & 20 \\
\hline \multicolumn{4}{|l|}{ Hot Carcass } \\
\hline Yield, lb & 823 & 903 & 850 \\
\hline Blue WF, gal / lb & 115 & 118 & 118 \\
\hline Total WF, gal / lb4 & 633 & 635 & 588 \\
\hline Total WP, lb / gal & 0.00158 & 0.00157 & 0.00170 \\
\hline \multicolumn{4}{|l|}{ Boneless meat ${ }^{6}$} \\
\hline Yield, lb & 576 & 632 & 595 \\
\hline Blue WF, gal / lb & 165 & 169 & 168 \\
\hline Total WF, gal / lb & 904 & 907 & 840 \\
\hline Total WP, lb / gal & 0.00111 & 0.00110 & 0.00119 \\
\hline \multicolumn{4}{|c|}{$\begin{array}{l}{ }^{1} \text { Modeled using data from } 2010 \text { Nebraska Beef Cattle Report, pp. 5-7; water utilization was calculated over } 365 \text { days for cows in } \\
\text { their respective systems and calf-system data averaged }\end{array}$} \\
\hline \multicolumn{4}{|l|}{${ }^{2}$ Rain water utilized } \\
\hline \multicolumn{4}{|c|}{${ }^{3}$ Surface and ground water utilized } \\
\hline \multicolumn{4}{|c|}{${ }^{4} \mathrm{WF}=$ water footprint (water unit $/$ carcass or boneless meat) } \\
\hline \multicolumn{4}{|c|}{${ }^{5} \mathrm{WP}=$ water productivity (carcass or boneless meat $/$ water unit) } \\
\hline${ }^{6}$ Assumes $70 \%$ of carcass & & & \\
\hline
\end{tabular}

Table 4. Effects of calf management on beef cattle system water utilization ${ }^{1}$

\begin{tabular}{|c|c|c|}
\hline \multirow[b]{2}{*}{ Item } & \multicolumn{2}{|c|}{ Calf system } \\
\hline & Calf-fed & Yearling \\
\hline \multicolumn{3}{|l|}{ Water use, gal } \\
\hline Green $^{2}$ & 443,187 & 433,714 \\
\hline Blue $^{3}$ & 105,704 & 96,081 \\
\hline Total & 548,891 & 529,795 \\
\hline$\%$ Green & 81 & 82 \\
\hline$\%$ Blue & 19 & 18 \\
\hline \multicolumn{3}{|l|}{ Hot Carcass } \\
\hline Yield, lb & 861 & 884 \\
\hline Blue WF, gal / lb & 123 & 109 \\
\hline Total WF, gal / lb ${ }^{4}$ & 638 & 599 \\
\hline Total WP, lb / $\mathrm{gal}^{5}$ & 0.00157 & 0.00167 \\
\hline \multicolumn{3}{|l|}{ Boneless meat ${ }^{6}$} \\
\hline Yield, lb & 603 & 619 \\
\hline Blue WF, gal / lb & 175 & 155 \\
\hline Total WF, gal / lb & 911 & 856 \\
\hline Total WP, lb / gal & 0.00110 & 0.00117 \\
\hline
\end{tabular}

${ }^{1}$ Modeled using data from 2010 Nebraska Beef Cattle Report, pp. 5-7; water utilization was calculated by averaging all cow system data and calculating water utilization for calf-feds while on feed for 215 days and yearlings grazing for 100 days followed by 146 days in the feedlot

${ }^{2}$ Rain water utilized

${ }^{3}$ Surface and ground water utilized

${ }^{4} \mathrm{WF}=$ water footprint (water unit / carcass or boneless meat)

${ }^{5} \mathrm{WP}=$ water productivity (carcass or boneless meat / water unit)

${ }^{6}$ Assumes $70 \%$ of carcass is boneless meat
Modeled effects of increasing the dietary inclusion of distillers grains in a typical Nebraska finishing diet on the water footprint of the finishing phase are shown in Table 5. In the scenario with no distillers in the diet, the water required in the finishing phase was 243,371 gallons. However, when distillers grains replaced a dry-rolled corn/high-moisture corn blend to $40 \%$ of dietary DM, the water utilized in the system decreased to 173,739 gallons. The complimentary effects of increased ADG and the lower water footprint of distillers grains compared to corn decreased the overall water footprint by $29 \%$. In the systems compared, the feedlot sector utilized 35\% of the total water while the cow-calf sector utilized the remaining $65 \%$. However, the feedlot sector utilized $63 \%$ of the blue water while the cow-calf sector utilized $37 \%$ of the blue water.

Utilizing corn residue and distillers grains decreased the water footprint of beef cattle production considerably; however, it is also important to focus on the use of green vs. blue water. In the complete beef systems modeled in this report, more than $80 \%$ of the water footprint was green water. Correctly quantifying and allocating blue and green water usage is essential when measuring the environmental impact of beef cattle production as green water falls as rain and does not require energy inputs to obtain, further increasing resource efficiency. Additionally, green water utilization likely has little impact on freshwater use and the hydrological cycle when the water is consumed by grazing animals in the form of grasses. This concept is especially true when grazed grasses are located on lands that would otherwise have no other use as the rain would fall and the grasses grow regardless of herbivory.

Two key questions about current methodology have arisen while completing these water footprints. Distinctions between green and blue water are critical. Green water use has a lower environmental impact than blue water use, and some argue has no impact. Comparing blue water use between systems is more meaningful than total water use. An advantage of cattle production is the ability to raise cattle in environments where green water is plentiful and can be utilized both for drinking and growing feeds. Secondly, the value added method of assigning water footprints to byproduct 
feeds is one of several potential methods. Assigning a water footprint to feeds with several products (corn grain, ethanol, corn processing feed products, corn residue) is complex and all current methods have biases or flaws. Improvements in this area are needed. Regardless of these setbacks it is clear that increases in feed use efficiency (more production of beef per unit of feed input) improves water productivity. In these systems over $99 \%$ of the water used was for feed production while less than $1 \%$ was utilized for drinking water by the animals. This underscores the need for improvements in feed use efficiency as well as water use efficiency by the crops.

\section{Implications}

While a substantial amount of water is used by the beef industry, it is paramount to understand where and how it is used on a systems basis and not assume a single averaged value. By obtaining this knowledge, a focus on improvement in resource use can be a target. Results of this study indicate the use of winter grazing corn residue and distillers grains are beneficial, as a secondary resource from the primary corn crop is utilized. The results of this study also emphasize the importance of efficiently and systematically utilizing resources. While there is room for improvement, over $80 \%$ of

Table 5. Effects of distillers grains inclusion in finishing rations on water use during finishing ${ }^{1}$

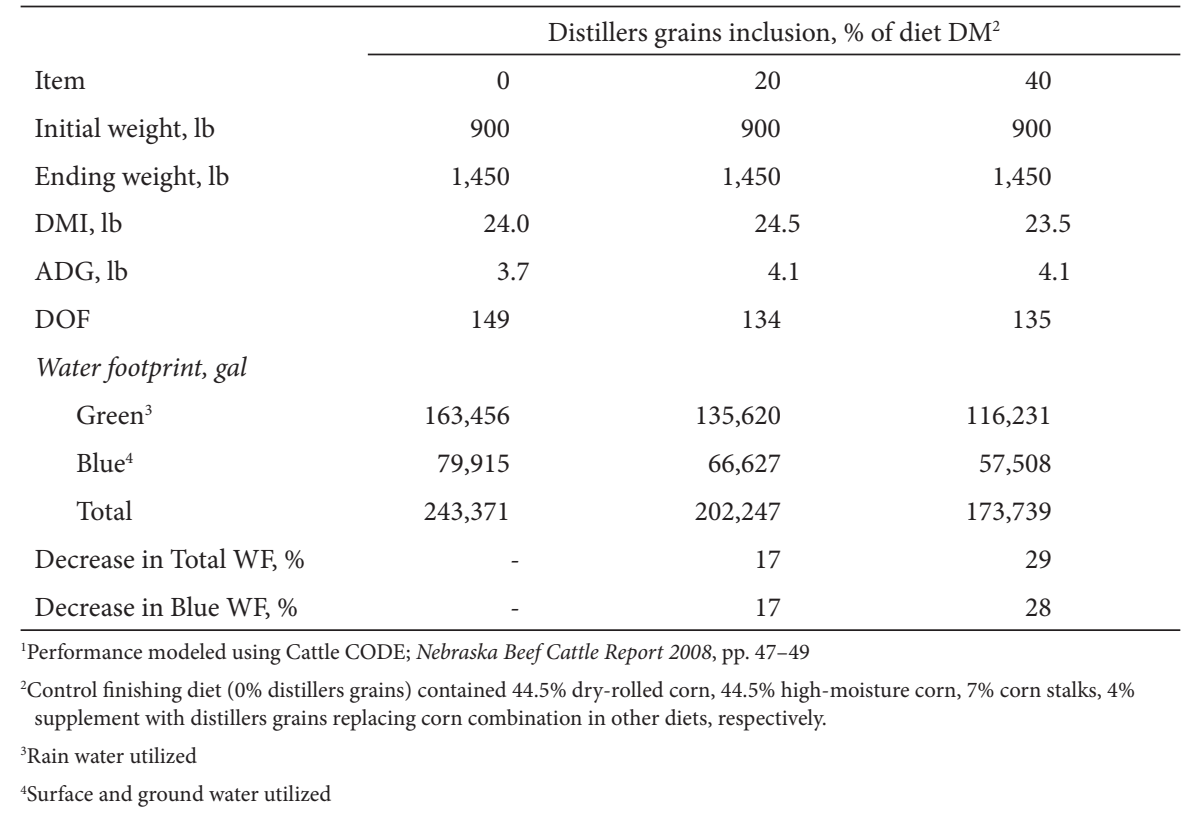

the water used to produce beef in a typical Nebraska system is green water, which minimizes the impact of beef production on freshwater use and the hydrological cycle relative to the ecosystem.

Tyler J. Spore, graduate student, Animal Science, Lincoln

Mesfin M. Mekonnen, research assistant professor, Daugherty Water for Food Global Institute, Lincoln
Christopher M. U. Neale, professor, Daugherty Water for Food Global Institute, Lincoln

Andrea K. Watson, research assistant professor, Animal Science, Lincoln

James C. MacDonald, professor, Animal Science, Lincoln

Galen E. Erickson, professor, Animal Science, Lincoln 